\title{
Measurement of circumference of the knee with ordinary tape measure
}

\author{
J. J. NICHOLAS, F. H. TAYLOR, R. B. BUCKINGHAM, AND D. OTTONELLO \\ From the Departments of Orthopedic Surgery, Medicine, and Community Medicine, School of Medicine, \\ University of Pittsburgh, Pennsylvania
}

\begin{abstract}
Nicholas, J. J., Taylor, F. H., Buckingham, R. B., and Ottonello, D. (1976). Annals of the Rheumatic Diseases, 35, 282-284. Measurement of circumference of the knee with ordinary tape measure. The circumference of the knees and thighs at three locations was measured in 10 patients on two consecutive occasions by three observers. Analysis of the results for interobserver, intraobserver and among-patient variation established that a change in circumference noted by different observers on two different days is significant if it exceeds $1.5 \mathrm{~cm}$ at the midpatella, $2.7 \mathrm{~cm}$ at $7 \mathrm{~cm}$ above, and $3.5 \mathrm{~cm}$ at $15 \mathrm{~cm}$ above the patella. If a single observer performs both measurements, the change need exceed only $1 \cdot 0,2 \cdot 0$, and $2 \cdot 7 \mathrm{~cm}$, respectively, to be significant.
\end{abstract}

The objective measurement of joint inflammation is a frequent research study, but often a neglected part of clinical evaluation (Boardman and Hart, 1967). The complicated equipment necessary for joint scanning and infrared photography, and even the measurement of the proximal interphalangeal and distal interphalangeal joints by jewellers' rings (Hart and Clark, 1951) and tape devices (Willkens, Gleichert, and Gade, 1973; Webb and others, 1973) undoubtedly discourage the adoption of these techniques for routine clinical evaluation. An ordinary tape measure would satisfy the need for simple, readily available equipment to measure joint circumference, an acknowledged index of joint inflammation.

The results of this study indicate that measurement of the knee with an ordinary tape measure provides reproducible results when used by both single and multiple observers.

\section{Methods}

Ten subjects were chosen at random from patients at the Rheumatology Clinic, School of Medicine, University of Pittsburgh, and showed a variety of conditions including degenerative joint disease, rheumatoid arthritis, normal knees, and knees which varied from obese to asthenic in conformation.

The measurements were performed in a quiet room, with a recording clerk and a physician present who measured and recorded dimensions of the right then the left leg in the following sequence: (1) midpatella, (2) $7 \mathrm{~cm}$ above the superior border of the patella, (3) $15 \mathrm{~cm}$ above the superior border of the patella. Measurements 8 were performed at these locations in the hope that they would reflect changes in fluid and synovial tissue (midpatella); muscle atrophy and fluid in the suprapatellar pouch $(7 \mathrm{~cm}$ above the patella); and atrophy of the quadriceps muscle $(15 \mathrm{~cm}$ above the patella). The sequence of measurements was repeated three times at each knee by the same examiner in the same order. Three physicians measured each patient at each sitting, and the entire examination was repeated approximately 2 weeks later on the same patient. Circumferential measurements were recorded to the nearest $0.1 \mathrm{~cm}$ with an ordinary tape measure.

An analysis of variance procedure was used to analyse the data (Sokal and Rohlf, 1969). The three sources of variability examined in this study were as follows. (1) The variability arising when a single observer made repeated measurements around the knee on the same patient, referred to subsequently as intraobserver variation. (2) The variability arising from differences between observers making measurements, referred to subsequently as interobserver variation. (3) The variability arising from differences in patients, subsequently referred to as amongpatient variation.

\section{Results}

A Table I gives the intraobserver variation for each of the three observers. The variation is reported for each of the combinations of time period, location of measurement, and left and right knee, e.g. the value $0.117 \mathrm{~cm}^{2}$ is the average intraobserver variation (averaged over the 10 patients) for observer 1, for 
Table I Intraobserver variation $\left(\mathrm{cm}^{2}\right)$ for various combinations of observer, time period, location of measurement, and left and right knee

\begin{tabular}{|c|c|c|c|c|c|c|}
\hline & Observer 1 & Observer 2 & Observer 3 & $\begin{array}{l}\text { Average } \\
\text { variation for } \\
\text { each leg }\end{array}$ & $\begin{array}{l}\text { Average } \\
\text { variation for } \\
\text { each time } \\
\text { period }\end{array}$ & $\begin{array}{l}\text { Average } \\
\text { variation for } \\
\text { each location }\end{array}$ \\
\hline \multicolumn{7}{|l|}{ Midpatella } \\
\hline $\begin{array}{l}\text { Time 1 } \\
\text { Right knee } \\
\text { Left knee } \\
\text { Average }\end{array}$ & $\begin{array}{l}0 \cdot 117 \\
0 \cdot 325 \\
0.221\end{array}$ & $\begin{array}{l}0 \cdot 144 \\
0 \cdot 155 \\
0 \cdot 150\end{array}$ & $\begin{array}{l}0.118 \\
0.050 \\
0.084\end{array}$ & $\begin{array}{l}0 \cdot 126 \\
0 \cdot 177\end{array}$ & $0 \cdot 151$ & \\
\hline $\begin{array}{l}\text { Time } 2 \\
\text { Right knee } \\
\text { Left knee } \\
\text { Average }\end{array}$ & $\begin{array}{l}0 \cdot 117 \\
0 \cdot 183 \\
0 \cdot 150\end{array}$ & $\begin{array}{l}0 \cdot 176 \\
0 \cdot 244 \\
0 \cdot 210\end{array}$ & $\begin{array}{l}0 \cdot 142 \\
0 \cdot 150 \\
0 \cdot 146\end{array}$ & $\begin{array}{l}0.145 \\
0.192\end{array}$ & $0 \cdot 169$ & \\
\hline Average period 1 and 2 & $0 \cdot 186$ & $0 \cdot 180$ & $0 \cdot 115$ & & & $0 \cdot 160$ \\
\hline \multicolumn{7}{|l|}{$7 \mathrm{~cm}$ above patella } \\
\hline $\begin{array}{l}\text { Time 1 } \\
\text { Right knee } \\
\text { Left knee } \\
\text { Average }\end{array}$ & $\begin{array}{l}0.542 \\
0 \cdot 158 \\
0.350\end{array}$ & $\begin{array}{l}0 \cdot 399 \\
1 \cdot 831 \\
1 \cdot 115\end{array}$ & $\begin{array}{l}0 \cdot 205 \\
0 \cdot 250 \\
0 \cdot 228\end{array}$ & $\begin{array}{l}0 \cdot 380 \\
0 \cdot 746\end{array}$ & 0.563 & \\
\hline $\begin{array}{l}\text { Time } 2 \\
\text { Right knee } \\
\text { Left knee } \\
\text { Average }\end{array}$ & $\begin{array}{l}0.608 \\
1.583 \\
1.096\end{array}$ & $\begin{array}{l}0.756 \\
0.156 \\
0.456\end{array}$ & $\begin{array}{l}0 \cdot 208 \\
0 \cdot 100 \\
0 \cdot 154\end{array}$ & $\begin{array}{l}0.524 \\
0.613\end{array}$ & 0.569 & \\
\hline Average period 1 and 2 & 0.723 & 0.786 & $0 \cdot 191$ & & & 0.566 \\
\hline $15 \mathrm{~cm}$ above patella & & & & & & \\
\hline $\begin{array}{l}\text { Time 1 } \\
\text { Right knee } \\
\text { Left knee } \\
\text { Average }\end{array}$ & $\begin{array}{l}0.483 \\
0.808 \\
0.646\end{array}$ & $\begin{array}{l}0.534 \\
0.170 \\
0.352\end{array}$ & $\begin{array}{l}0.225 \\
0.605 \\
0.415\end{array}$ & $\begin{array}{l}0.414 \\
0.528\end{array}$ & 0.471 & \\
\hline $\begin{array}{l}\text { Time } 2 \\
\text { Right knee } \\
\text { Left knee } \\
\text { Average }\end{array}$ & $\begin{array}{l}1 \cdot 083 \\
1 \cdot 125 \\
1 \cdot 104\end{array}$ & $\begin{array}{l}3 \cdot 615 \\
2 \cdot 743 \\
3 \cdot 179\end{array}$ & $\begin{array}{l}0 \cdot 197 \\
0 \cdot 208 \\
0 \cdot 203\end{array}$ & $\begin{array}{l}1.632 \\
1.359\end{array}$ & 1.495 & \\
\hline Average period 1 and 2 & 0.875 & $1 \cdot 766$ & $0 \cdot 309$ & & & 0.983 \\
\hline
\end{tabular}

measurements made at midpatella, on the right knee. At the midpatella location the three observers had very similar performances as reflected by the average intraobserver variation (average over time period and right and left leg); at $7 \mathrm{~cm}$ above the patella observers 1 and 2 are similar with respect to their intraobserver variation and both have a larger value than that for observer 3 . At $15 \mathrm{~cm}$ above the patella observer 3 has the smallest intraobserver variation and observer 2 the largest.

B The intraobserver variation averaged for each leg is given in Table I. With one exception, that of the location $15 \mathrm{~cm}$ above the knee, for the time period 2 , the average intraobserver variation for the left leg was higher than for the right leg.

C The intraobserver variation for each location and time period averaged over the two legs and the three observers is given in Table I.
D The average components of variation, that is the components reflecting intraobserver, interobserver, and among-patient variations for each site of measurement, are given in Table II. The variability arising from differences among patients represents approximately $95 \%$ of the total variation. The remaining two components have approximately equal shares of the remaining $5 \%$ of the total variation. The relationship of the various components to the total variation of the measurements persists at all three sites of measurement.

\section{Discussion}

In this study the intraobserver and interobserver variations were smallest at the midpatella and increased as the location of measurement moved from the midpatella to 7 and $15 \mathrm{~cm}$ above the 
Table II Estimated components of variance for each location of measurement *

\begin{tabular}{|c|c|c|c|c|c|c|c|c|c|}
\hline & \multicolumn{3}{|c|}{ Midpatella } & \multicolumn{3}{|c|}{$7 \mathrm{~cm}$ above midpatella } & \multicolumn{3}{|c|}{$15 \mathrm{~cm}$ above midpatella } \\
\hline & $A \dagger$ & $B \ddagger$ & $C \S$ & $A$ & $B$ & $C$ & $A$ & $B$ & $C$ \\
\hline $\begin{array}{l}\text { Intraobserver variation } \\
\text { Interobserver variation } \\
\text { Patient variation }\end{array}$ & $\begin{array}{r}0 \cdot 160 \\
0 \cdot 124 \\
10 \cdot 051\end{array}$ & $\begin{array}{l}0 \cdot 400 \\
0 \cdot 352 \\
3 \cdot 170\end{array}$ & $\begin{array}{r}1 \cdot 55 \\
1 \cdot 20 \\
97 \cdot 25\end{array}$ & $\begin{array}{r}0.566 \\
0 \cdot 364 \\
25 \cdot 462\end{array}$ & $\begin{array}{l}0.752 \\
0.603 \\
5 \cdot 046\end{array}$ & $\begin{array}{r}2 \cdot 14 \\
1 \cdot 38 \\
96 \cdot 48\end{array}$ & $\begin{array}{r}0 \cdot 983 \\
0 \cdot 577 \\
36 \cdot 112\end{array}$ & $\begin{array}{l}0.992 \\
0.760 \\
6 \cdot 009\end{array}$ & $\begin{array}{r}2.61 \\
1.53 \\
95.86\end{array}$ \\
\hline Total & $10 \cdot 335$ & & & $26 \cdot 392$ & & & $37 \cdot 672$ & & \\
\hline
\end{tabular}

* Based upon estimates pooled over time period and left and right leg.

$\dagger$ Estimated component of variation $\left(\mathrm{cm}^{2}\right)$.

$¥$ Square root of component $=$ standard deviation $(\mathrm{cm})$.

$\$$ Percent of total variation.

superior border of the patella. The relationship of intraobserver, and among-patient variation to the total variation remained the same from location to location.

Estimates of intraobserver variation can be used to place statistical limits on a single measurement made by a physician. If, for example, such limits are wanted for a single measurement $X$ at the midpatella, and these limits were to include $95 \%$ of such situations, then the limits would be $X \pm 1.96 \sqrt{0.16}$ or $X \pm 0 \cdot 8$. At $7 \mathrm{~cm}$ and $15 \mathrm{~cm}$ above the knee these limits would be respectively $X \pm 1.96 \sqrt{0.566}=X \pm$ 1.5 , and $X \pm 1.96 \sqrt{0.983}=X \pm 1.9$.

Two successive measurements made on the same patient by the same physician are correlated as a consequence of their having come from the same patient. However, there is no satisfactory manner in which the observations made in the present study can be paired to take into account the correlations of two successive measurements made on the same patient. If the existence of this correlation is ignored for the moment, the estimate of intraobserver variation may be applied to give conservative bounds for a difference in two measurements on the assumption that the only source of variation arises from intraobserver error. At midpatella, then, the absolute difference between two measurements should exceed about $1 \mathrm{~cm}$ in order that this absolute difference can be considered significant statistically at the 0.05 level.*

If both intraobserver and interobserver variation are present, as in the case of individual measurements made by two different physicians, then the absolute difference between the two measurements at midpatella must exceed about $1 \cdot 5 \mathrm{~cm}$. $\dagger$ For the locations $7 \mathrm{~cm}$ above the patella the corresponding values for the above situations are respectively $2 \mathrm{~cm}$ and $2.7 \mathrm{~cm}$, and for the locations $15 \mathrm{~cm}$ above the patella the values are respectively 2.7 and $3.5 \mathrm{~cm}$.

The observation that variation was greate more frequently in the left leg than the right may te because the right leg lay nearer the physician and was measured first. The observation that error increased as the site of observation became more superior to the patella was probably due to the cylindrical shape of the thigh, since the circumference of a cone varies significantly as one moves along the long axis.

* The standard error of the difference is $\sqrt{V\left(X_{1}+V\left(X_{2}\right)\right.}$ where $V\left(X_{1}\right)$ and $V\left(X_{2}\right)$ are the intraobserver variances attached to the two measurements. The critical value for the absolute difference is thus $1.96 \sqrt{V\left(X_{1}\right)+V\left(X_{2}\right)}=1 \cdot 1$.

$\dagger$ Based on the assumption of Gaussian distribution of errors in the differences.

\section{References}

BOARDMan, P. L., AND HART, F. D. (1967) Brit. med. J., 4, 264 (Clinical measurement of the anti-inflammatory effects of salicylates in rheumatoid arthritis)

HART, F. D., AND Clark, C. J. M. (1951) Lancet, 1, 775 (Measurement of distal swelling in rheumatoid arthritis)

SOKAL, R. R., AND RoHLF, T. J. (1969) in 'Biometry', pp. 209 and 328. Freeman, San Francisco

WebB, J., DoWnie, W. W., Dick, W. C., AND LeE, P. (1973) Scand. J. Rheum., 2, 127 (Evaluation of digital joint circumference measurements in rheumatoid arthritis)

Willkens, R. F., Gleichert, J. E., AND Gade, E. T. (1973) Ann. rheum. Dis., 32, 585 (Proximal interphalangeal joint measurement by arthrocircameter) 